\title{
Introduction
}

\section{Eloranta, Jari Antero}

Routledge

2019-01-01

Eloranta , J A , Golson , E , Hedberg , P \& Moreira , M C 2019 , Introduction . in J Eloranta , E Golson, P Hedberg \& M C Moreira (eds), Small and Medium Powers in Global History : Trade, Conflicts, and Neutrality from the 18th to the 20th Centuries. Perspectives in Economic and Social History, Routledge , Abingdon , pp. 1-26 . https://doi.org/10.4324/9781315180946-1

http://hdl.handle.net/10138/312684

https://doi.org/10.4324/9781315180946-1

acceptedVersion

Downloaded from Helda, University of Helsinki institutional repository.

This is an electronic reprint of the original article.

This reprint may differ from the original in pagination and typographic detail.

Please cite the original version. 


\section{Eloranta et al.}

Introduction

\section{Introduction}

\section{Jari Eloranta, Peter Hedberg, Maria Cristina Moreira, and Eric Golson}

The history of trade and conflicts for the last 300 years is typically a story of great powers and great men (and occasionally women), where the smaller states are usually referred to in footnotes. It is, after all, a common assumption that smaller geographic size, or some other indicator of perceived weakness, connotes limited power and importance in the "big picture". In this volume the authors challenge this view. In fact, we would argue that smaller/weaker states have had crucial roles to play in history, especially during conflicts. As warfare has become more consuming, conflicts bigger and deadlier, and more and more of a country's resources are used up in order to win the war, smaller/weaker states have been able to take advantage of the economic opportunities that conflicts can offer. It is, of course, true that smaller nations can end up on the receiving end of military aggression, but in our view they have also been very adept at maneuvering during conflicts, thereby avoiding invasion and direct participation in the war. Thus, we are calling here for greater attention to be paid to the middle and small powers in world history and suggesting that a preoccupation with the study of great powers can distort our view of the nuanced dimensions of conflicts and trade. After all, networks and alliances have always been crucial in warfare, and they have worked only if everyone contributed.

The aim of this edited volume is thus to provide a novel take on the history of conflicts and trade, with a clear focus on the role of small/medium, or "weak", and often neutral states. This volume spans a crucial period in history, namely, from the 18th century with its great power expansion revolutions to the world wars and the Cold War of the 20th century, i.e., crucial periods of change in the concept and practice of neutrality and trade, as well as periods of transition in the nature and technology of warfare. The key findings from the case studies included in this volume 
emphasize that these states played a much bigger role in world and bilateral trade than has previously been assumed, and that this role was augmented by the emergence of truly global conflicts and total war. In general, we want to explore what kinds of short- and long-run changes we see in the trade flows between the great powers and weaker states during these centuries, especially whether the pressure of a war effort allowed more latitude for these states to explore their trade options or enhanced their bargaining power or market position. Many of the smaller/weaker states were neutral during parts or all of the major conflicts of the period and served as important conduits for key strategic and other goods. The basic argument in most of the chapters here is that weak states were able to expand their trade and discover new markets during the large and protracted conflicts, which more and more characterized this period, due to the industrialization of war.

In what follows, we first discuss the study of smaller/weaker states, state power, and conflicts. After this, we provide an overview of some of the perspectives on the study of trade, as well as the macro-indicators of trade over time. The big changes in the last 300 years involve the rise and fall of powerful states (and the less powerful), the massive increases in world trade, especially since the globalization and industrialization of the 19th century; increases in the scale and scope of conflicts; and the global increases in living standards. None of these processes has been steady or even, and thus they have created winners and losers. We conclude this introduction with a review of the chapters and raise some points about the future research challenges.

\section{Weak states, state economic/political power, and conflicts}

Given our strong assertions about smaller/weaker states, it is useful to discuss what we mean by this term. A state that occupies a "small" geographic area is not necessarily weak (consider Great Britain), while on occasion states of wide geographic extent (such as China in the 19th century) need not be strong. In the present volume we focus our analysis primarily on states that had limited economic and/or military power. ${ }^{1}$ Thus, for example, the United States in the 18 th century was clearly a weak state, whereas the USA that emerged after World War II was most certainly not. In this section we explore different ways of estimating the power of a 
state, and also how many conflicts we have seen in this period, roughly from the mid18 th century to the Cold War, and what kinds they were.

Here the definition of weak states is not the same as that of failing states, i.e., states which cannot contain internal violence and repression, such as is used in the recent literature on state formation. ${ }^{2}$ Our approach is more akin to that of Michael Handel, who argues that even countries with a large area can be weak, in the sense that they are weak players in the international system. Typically, according to him, a weak state tends to have a small population and area, low GNP, a small and specialized domestic market, high dependence on foreign military protection, and limited potential to influence the international system. ${ }^{3}$ In Jari Eloranta's earlier work, weak states are presented as perhaps overly dependent on external trade, with fewer policy constraints on domestic trade apparatus, and differing from one another on the basis of geographic and strategic impulses. ${ }^{4}$ Moreover, they can have significant options in the global or regional system depending on the relations between them and the great powers and the characteristics of the hegemonic system. As Robert Gilpin and Paul Kennedy, among others, point out, systems dominated by hegemonic powers can be more peaceful than others, since other powers cannot challenge them, thus leaving room for smaller/medium powers to gain from the economic and political networks. ${ }^{5}$

There is, of course, a large literature on state capacity in history, and it is a particularly lively field in economic history. ${ }^{6}$ An equally large literature has been devoted to the evolution of fiscal states and fiscal transformations in history. ${ }^{7}$ Many of these topics intersect when it comes to analyzing the long-run formation of states, typically in Europe, usually via fiscal expansion impacted by conflicts. ${ }^{8}$ The scholars working on state capacity have overwhelmingly used fiscal data - for example, revenue collection and tax analysis - to gauge a state's ability to establish a monopoly of the violence inside its borders. Usually the analysis of conflicts brings in the ability to use public debt as a tool to finance them and shows how the burden of debts affected state formation. ${ }^{9}$ Here our focus is not on the growth and evolution of fiscal capacity, but on military capacity and the level of engagement in trade. We particularly want to compare and contrast the position of smaller/weaker states with that of the great powers. Finally, we want to emphasize that the power position of 
states changed over time, and we want to see if this also holds for smaller/weaker states.

One way to analyze the power position and ranking of states has been to use the so-called CINC (Composite Index of National Capacity) scores, especially in the conflict and peace science research since the 1970s. This index consists of total population, urban population, iron and steel production, energy consumption, military personnel, and military expenditure, all from 1816 onwards. ${ }^{10}$ This index is useful in forming a macro-picture of power relations over time, but it also has some weaknesses. First, it can overestimate the perceptions of power versus actual capacity. Second, some of the components can be critiqued, such as the inclusion of two population variables and the lack of GDP (per capita) as a component, especially since more and more of these data are available for the post-1816 period. ${ }^{11}$ Still, the CINC scores are a decent starting point for our analysis here.

$<<$ Table 1.1 HERE >>

Table 1.1

Composite Indices of National Capabilities (CINC), 1865-1950, as shares (\%) of UK CINC

\begin{tabular}{|l|l|l|l|l|l|l|l|}
\hline & 1865 & 1880 & 1895 & 1913 & 1925 & 1938 & 1950 \\
\hline BRA & 2.73 & 4.13 & 5.23 & 9.73 & 11.46 & 12.82 & 21.31 \\
\hline DEN & 1.56 & 1.38 & 1.74 & 1.77 & 2.08 & 2.56 & 3.28 \\
\hline FRA & 43.36 & 49.54 & 51.74 & 60.18 & 62.50 & 58.97 & 54.10 \\
\hline GER & 25.39 & 48.62 & 73.26 & 126.55 & 85.42 & 197.44 & - \\
\hline NOR & 0.78 & 1.83 & 1.16 & 2.65 & 3.13 & 3.85 & 0.00 \\
\hline POR & 1.95 & 2.29 & 2.33 & 2.65 & 4.17 & 3.85 & 3.28 \\
\hline SWE & 4.30 & 5.05 & 5.23 & 6.19 & 6.25 & 6.41 & 8.20 \\
\hline NED & 3.13 & 4.13 & 4.65 & 6.19 & 7.29 & 6.41 & 13.11 \\
\hline
\end{tabular}




\begin{tabular}{|l|l|l|l|l|l|l|l|}
\hline UK & 100.00 & 100.00 & 100.00 & 100.00 & 100.00 & 100.00 & 100.00 \\
\hline USA & 52.73 & 57.34 & 97.67 & 194.69 & 264.58 & 219.23 & 465.57 \\
\hline
\end{tabular}

Sources: National Material Capabilities data 5.0, based on methods developed in Singer, Bremer, and Stuckey (1972).

Note

$\mathrm{BRA}=$ Brazil, DEN $=$ Denmark, FIN $=$ Finland, FRA $=$ France, GER $=$ Germany, $\mathrm{NED}=$ Netherlands, NOR $=$ Norway, $\mathrm{POR}=$ Portugal, $\mathrm{SWE}=$ Sweden, $\mathrm{SWI}=$ Switzerland, UK=United Kingdom, and USA=United States of America.

Note

We use the period from 1865 onward to make these figures comparable with the naval tonnage data noted later in this chapter.

Based on the CINC scores, Brazil, Denmark, Norway, Sweden, and the Netherlands were fairly consistently weak powers in the period summarized in Table 1.1. France and the UK appear to have been declining great powers, while the USA was an ascending power, especially after World War I. Germany's power status waxed and waned in the period; in the 1920s, for example, it was a weak great power.

Military spending is more naturally taken as a comparative instrument of a state's (military) capacity. However, it too is imperfect, since the COW-database figures have been converted to pounds sterling or dollars using exchange rates. Another option would be to come up with the percentage share of military spending in respect of GDP, often called the military burden. However, the data for all these countries are not available, so we have opted here to use the COW figures. However, we treat them as a percentage share of the world's military spending total (= all COW military expenditures summed annually). ${ }^{12}$

$<<$ Table 1.2 HERE $>>$

Table 1.2

Military spending of select nations as a share of the world's military spending (\%),

1865-1950

\begin{tabular}{|l|l|l|l|l|l|l|l|}
\hline & 1865 & 1880 & 1895 & 1913 & 1925 & 1938 & 1950 \\
\hline
\end{tabular}




\begin{tabular}{|l|l|l|l|l|l|l|l|}
\hline BRA & 1.44 & 1.59 & 1.34 & 1.42 & 1.08 & 0.27 & 0.75 \\
\hline DEN & 0.38 & 0.47 & 0.49 & 0.28 & 0.21 & 0.11 & 0.12 \\
\hline FRA & 16.78 & 19.95 & 15.83 & 11.27 & 7.13 & 4.40 & 3.34 \\
\hline GER & 4.19 & 11.79 & 13.60 & 14.94 & 3.25 & 35.45 & - \\
\hline NOR & - & - & - & 0.19 & 0.16 & 0.06 & 0.11 \\
\hline POR & 1.38 & 1.59 & 1.40 & 0.90 & 0.39 & 0.24 & 0.23 \\
\hline SWE & 0.60 & 0.77 & 0.90 & 0.77 & 0.93 & 0.35 & 0.49 \\
\hline NED & 1.30 & 1.68 & 1.34 & 0.74 & 0.85 & 0.36 & 0.53 \\
\hline UK & 14.76 & 13.04 & 15.74 & 11.45 & 12.74 & 8.91 & 5.33 \\
\hline USA & 21.45 & 6.94 & 6.69 & 10.62 & 12.95 & 5.41 & 32.64 \\
\hline SOurC: NG & & & & & & & \\
\hline
\end{tabular}

Source: National Material Capabilities data 5.0, based on methods developed in Singer, Bremer, and Stuckey (1972).

In the late 19th century, the only great powers shown in Table 1.2 were the UK and France - the United States had a high military spending share in 1865 only because of the impact of the Civil War, and in subsequent years this share was much smaller. The medium powers here were Germany and the USA, and both were ascending to the status of great powers by 1913, Germany in particular. In the interwar period those rankings changed, and on the eve of World War II Germany was the only military superpower among this group. After the war, it was the USA. The military spending "strength" of the weak powers here did not change very dramatically during the period, although they show a clear trend toward lower relative spending after World War I.

The great leaps in the extension of historical national accounts in the last 40 years have made it possible to look at the relative positions of these states in the 19th and 20th centuries, and sometimes, as in the cases of the UK and Sweden, for longer. ${ }^{13}$ GDP is one way to measure the overall economic capacity, and it is particularly well suited for comparisons of the great powers and their ability to prevail in a conflict. 
However, for example, GDP per capita is in many ways a better measure than the CINC score, since it describes concisely a state's total economic capacity and its potential for mobilization during a conflict. Moreover, it takes into account the size of the population, which can, when large, be both a positive (numbers available for military service, ability to mobilize, ability to sustain losses) and a negative (being hard to control, with potential for revolution, cost to a sovereign of appeasing a large population). At least it gives us another way to analyze state capacity in a comparative way.

$<$ Table 1.3 HERE >>

Table 1.3

Real GDP per capita (in 2011 USD), 1800-1950

\begin{tabular}{|l|l|l|l|l|l|l|l|l|l|l|}
\hline & \multicolumn{2}{|l}{1800} & \multicolumn{2}{l}{1850} & \multicolumn{2}{l}{1900} & & & & \\
& $\begin{array}{l}\text { GDP } \\
\text { per } \\
\text { capita }\end{array}$ & $\begin{array}{l}\text { World } \\
\text { rank }\end{array}$ & $\begin{array}{l}\text { GDP per } \\
\text { capita }\end{array}$ & $\begin{array}{l}\text { World } \\
\text { rank }\end{array}$ & $\begin{array}{l}\text { GDP per } \\
\text { capita }\end{array}$ & $\begin{array}{l}\text { World } \\
\text { rank }\end{array}$ & $\begin{array}{l}\text { GDP per } \\
\text { capita }\end{array}$ & $\begin{array}{l}\text { World } \\
\text { rank }\end{array}$ & $\begin{array}{l}\text { GDP per } \\
\text { capita }\end{array}$ & World rank \\
\hline BRA & 600 & 16 & 600 & 34 & 606 & 43 & 1549 & 84 & 8316 & 72 \\
\hline FIN & 827 & 13 & 1035 & 23 & 1813 & 24 & 5208 & 22 & 32972 & 23 \\
\hline FRA & - & - & 2028 & 11 & 4214 & 12 & 6869 & 15 & 31771 & 26 \\
\hline GER & 958 & 11 & 1386 & 18 & 4596 & 9 & 5536 & 20 & 33975 & 19 \\
\hline NOR & - & - & 1562 & 15 & 3813 & 14 & 7947 & 12 & 54594 & 4 \\
\hline POR & 1330 & 7 & 1226 & 22 & 1729 & 25 & 2771 & 48 & 21497 & 37 \\
\hline SWE & 1151 & 9 & 1446 & 16 & 3438 & 15 & 8816 & 9 & 36374 & 13 \\
\hline SWI & - & - & $2333 *$ & $7 *$ & 5124 & 6 & 9053 & 8 & 42752 & 7 \\
\hline UK & 2205 & 1 & 2858 & 1 & 5608 & 5 & 9441 & 6 & 34390 & 18 \\
\hline USA & 1980 & 3 & 2825 & 2 & 6252 & 1 & 15241 & 1 & 45887 & 5 \\
\hline
\end{tabular}

Source: Maddison Project Database, version 2018. See Inklaar, de Jong, Bolt, and van Zanden (2018). The figures are in 2011 USD, based on multiple benchmarks. 
$\mathrm{BRA}=$ Brazil, FIN $=$ Finland, FRA $=$ France, GER $=$ Germany, NOR $=$ Norway, $\mathrm{POR}$ $=$ Portugal, $\mathrm{SWE}=$ Sweden, $\mathrm{SWI}=$ Switzerland, UK $=$ United Kingdom, and USA = United States of America.

$*=$ for Switzerland, the value is the 1851 figure, the earliest data point.

The selected countries are analyzed in Table 1.3 in terms of both their real GDP per capita (as potential for mobilization) and rank in global comparisons. First, however, we must note that the rankings take account of the fact that few countries had any data for the early part of the period, and that they do not say anything about the absolute size of the economy. If we start with the UK and the USA, the former unquestionably experienced a decline in the 20th century, similar to the pattern apparent from previous tables. The United States ascended to the top and held on to this position until the late 20th century. France also declined toward the late 20th century. Germany, in its turn, ascended in the early 20th century, but then dropped to the same rank as it occupied for most of the period. Of the smaller/weaker states, Brazil evinced little progress, and in fact declined in rank. The Nordic countries remained at similar levels, relatively speaking, with some rise in the ranks, notably by Norway.

Another way to assess a state's military capacity more effectively is to analyze its military capacity as a stock. Scholars have in the past used the number of battleships as a measure of state capacity, which favors the great powers. ${ }^{14}$ Naval tonnage is a better way to gauge naval capacity, and a new dataset offers us a way also to take into account proportional naval power. ${ }^{15}$ Figure 1.1 provides us with the great power patterns, and Figure 1.2 what happened to some of the smaller/weaker states. Unsurprisingly, the UK dominated the waves until World War I. Afterwards, it had close to parity with the USA. The latter country's performance in this comparison is quite surprising - typically scholars do not consider the US a major naval power, at least until World War II. But the interwar naval treaties limited naval buildup to a degree in any case. France was a declining naval power for most of the period, while Germany was ascending (yet unable to challenge most of the others) until the interwar period. These comparisons may change our perceptions of power in the period, although the trends are somewhat similar to the other indicators used above. Regardless of these patterns, we have to acknowledge that having large battleships, 
submarines, and later aircraft carriers was vital for global dominance such as UK in the 19th century and US in the 20th. From this perspective, the US was less impressive before World War II. In 1860, the American navy had only five ships of the line, whereas the UK had $76 .{ }^{16}$

In turn, the patterns for the weaker states were extremely varied. For example, Brazil was a substantive naval power in the latter part of the 19th century, with levels on par at times with the US and Germany. Portugal and Norway were fairly similar, with a lowering trend from 1900 onwards, and Sweden increased its naval power in the early 20th century, following Brazil's development in the interwar period. The naval power indices of the weaker powers were around 10-15 percent of the totals of the major powers. It appears that the weaker powers were not a uniform group but more a set of groups, which then followed similar trends, most probably due to external influences (conflicts, markets, etc.).

\section{Figure 1.1}

\section{Total proportional tonnage of France, Germany, UK, and USA, 1865-1950.}

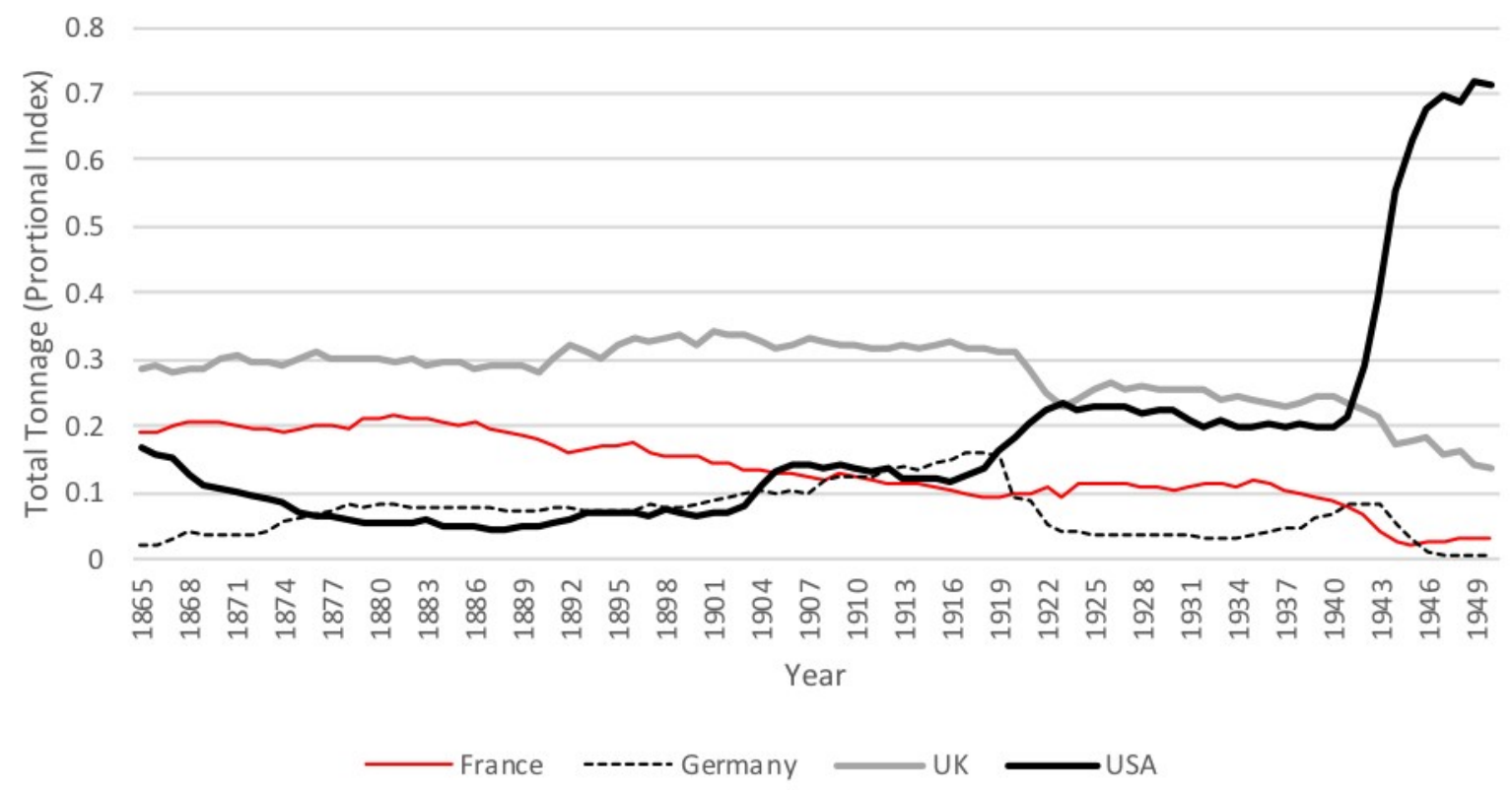

Source: Crisher and Souva (2014).

Figure 1.2

Total proportional tonnage of Brazil, Portugal, Norway, and Sweden, 1865-1950. 


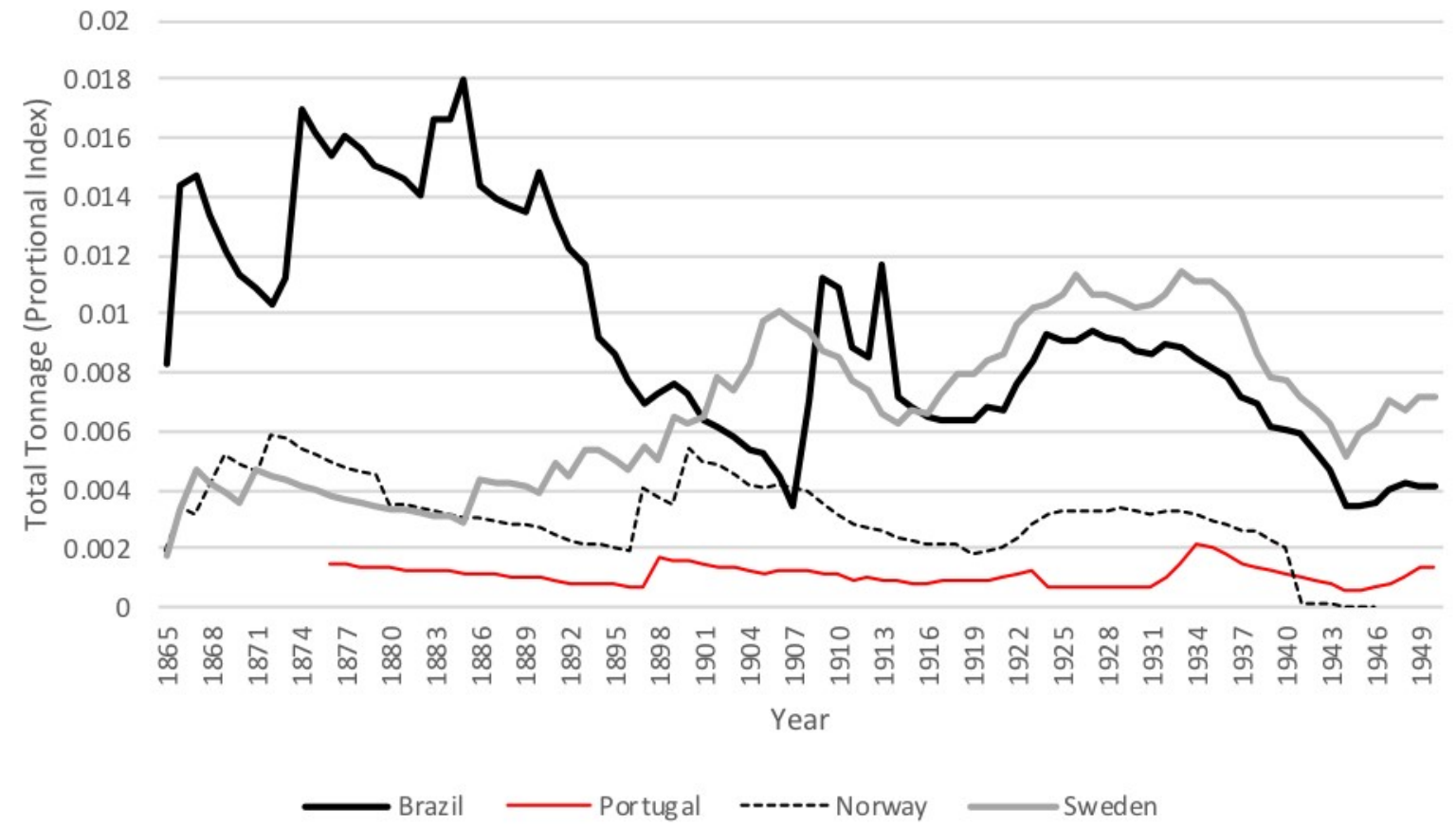

Source: Crisher and Souva (2014).

One of the key external conditions that affected all the states in the global trading system was conflict. While the 19th and 20th centuries saw fewer conflicts overall in fact, the "long 19th century" from 1815 to 1914 saw few of them - they were deadly centuries. The world wars were, of course, the deadliest conflicts; they developed into global total wars, something that had begun with the wars of the French Revolution and Napoleonic conflicts. These total wars, which were relatively rare, involved all elements of society, and typically also offered new opportunities for neutral and smaller states, due to the resource needs of the belligerents. ${ }^{17}$

Figure 1.3

Total deaths (military and civilian) from conflicts, 1750-1950. 


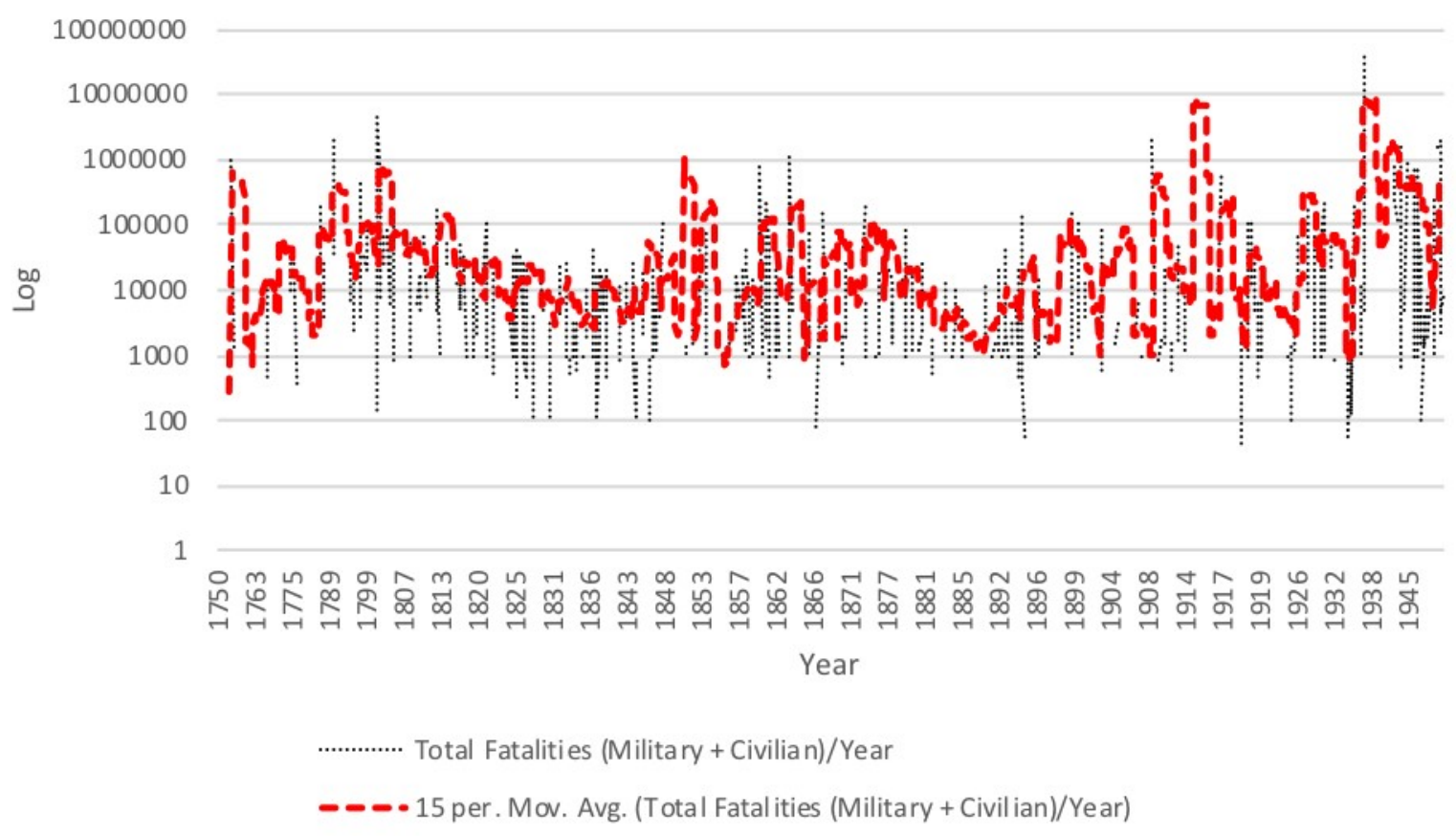

Source: Conflict Catalog (Violent Conflicts 1400 AD to the Present in Different Regions of the World), retrieved from www.cgeh.nl/data\#conflict (cited February 10, 2018).

As Figure 1.3 shows, the long-run trends in war fatalities, military and civilian, hardly decreased from the 1750 s to 1945 . There was a slight decline in the early 19 th century, then an increase in the mid-century, and more fluctuation and increases due to the world wars. Since the Conflict Catalog figures are still somewhat incomplete, we also decided to confirm the results with the COW data, as shown in Figure 1.4. From 1823, the data show many annual fluctuations and apparently a slightly increasing trend toward the late 19th century and then into the 20th. The biggest jump came with World War I, and then the interwar period. There is certainly no reduction in conflict-related violence.

Figure 1.4

Total battle deaths, 1823-1950. 


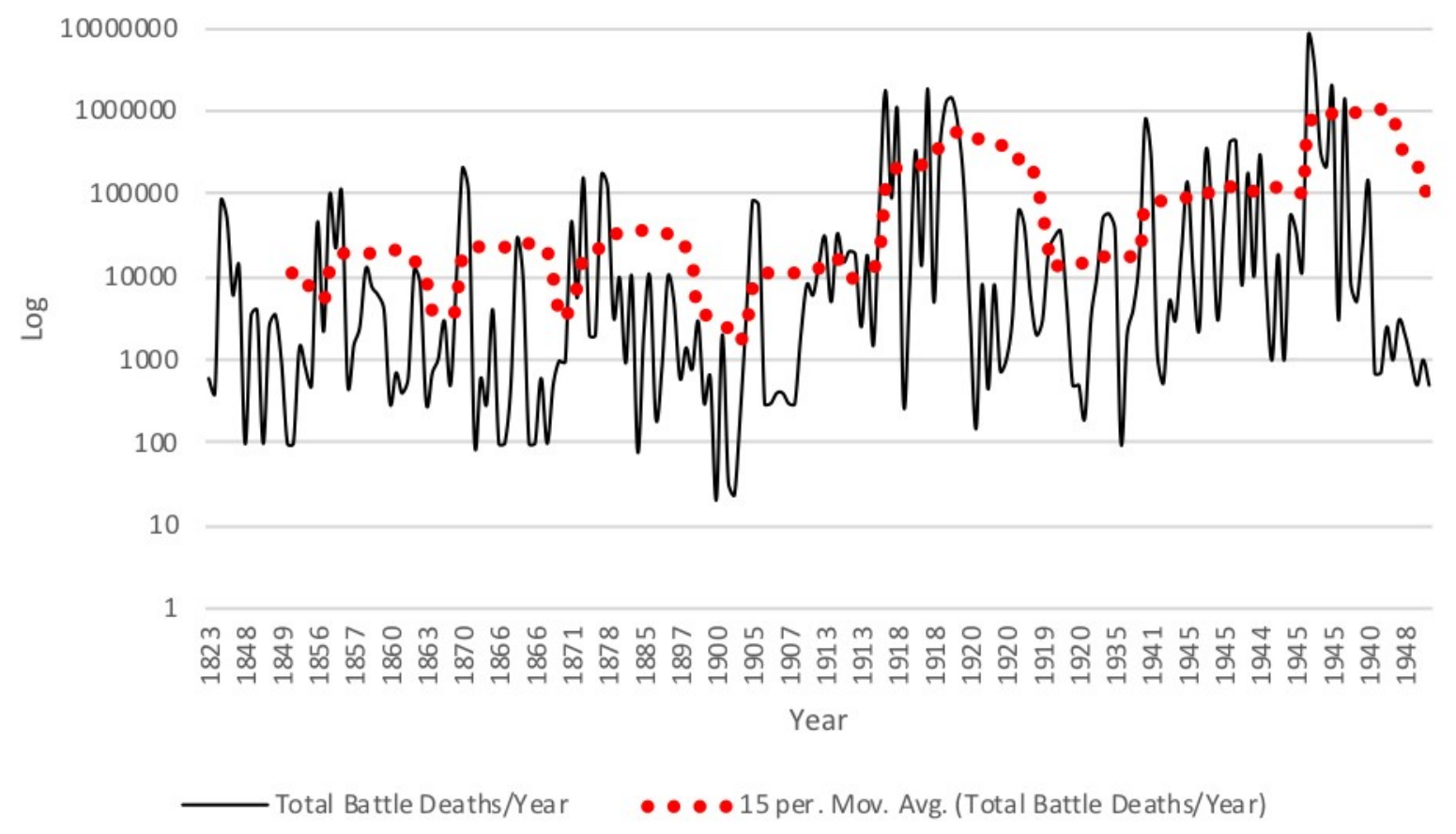

Source: Inter-State War Data, ver. 4.0. See also Sarkees and Wayman (2010). Please note that this database starts in 1816, and the first observations are from 1823 onward.

\section{Importance of the study of trade and neutrality}

Since the 17th century, major wars have recurrently been accompanied by declining international commerce. ${ }^{18}$ There are several reasons for this. Developments in communications and societal organization have enabled more efficient mobilization for war while increasing the production capacity of states has entailed mass production of war materials, population growth has provided for larger armies, and advances in weaponry have worsened the adverse impact of wars on the economy over time. In addition to tragic losses of lives, numbers of wounded, and ruined material resources, wars and conflicts have persistently distorted markets and disrupted trade. Moreover, and of great importance to this book, after the turn of the 18th century, naval warfare and blockades have been employed and more vigorously enforced than before. The power of a country is typically related to its wealth, i.e., resources buy guns und munitions, foodstuffs, and raw materials, and commodities, which are required to provide for military as well as civilian needs. For this reason, belligerent countries have regularly made efforts to control trade channels, either to benefit from trade in order to increase their wealth, or to deprive the enemy of their resources. ${ }^{19}$ 
Belligerent countries commonly have accounted for the largest market distortions and trade disruptions. A great number of powers that have waged war against each other have been leading trading nations and each other's major trading partners, and as they have targeted each other the naval warfare and blockade policies of belligerent powers have frequently entailed losses of major markets. Consequently, the decline in the trade of belligerent countries has been strongest. ${ }^{20}$ This has opened up opportunities for other nations to fill the void.

Moreover, the impact of wars and conflict on the economy has commonly stretched far and deep beyond belligerent countries. ${ }^{21}$ Since the 18th century, trade and integration has increased on a global level. As a result, an increasing number of countries have depended on international trade for their economic growth and development and have thus been increasingly vulnerable to disruptions of international trade and commerce. The larger the trading nations and the more vigorous naval warfare has been, the stricter the blockade that has been enforced. In addition, this has resulted in greater market distortions, and as a result the costs of trade have increased. The costs from market distortions and declining international commerce and trade have sometimes exceeded the direct costs from battle-related casualties and material destruction. ${ }^{22}$ For this reason, the resulting decrease in world trade volumes has been assumed to affect both belligerents and non-belligerents neutral countries - negatively. ${ }^{23}$

However, as is presented in this book, there are ample examples of neutral countries that have benefitted from the changing political and economic conditions brought on by wars and conflicts. ${ }^{24}$ Neutral maritime trade and wars have coexisted since at least the 18th century, and since then commercial activities of neutral countries have not been as restricted as the belligerents'. While international trade and commerce has declined, the importance of access to alternative markets and the role of neutral trade conversely has increased. ${ }^{25}$ As a result, neutral countries have had opportunities to profit from international wartime demand. Even though such expansions have been temporary - as hostilities eventually have ceased and international commerce have been resumed - they sometimes have entailed long-term positive impact on trade and GDP growth. ${ }^{26}$ When the trade between belligerent countries has diminished due to naval warfare and blockades, neutral countries have 
often managed to maintain old and develop new channels for international commerce. In this respect, expanding wartime trade of neutral countries has mitigated the negative impact of conflicts and wars on the economy in general.

\section{Figure 1.5}

Estimates of the economic dimensions of early modern shipping, 1450-1800 vs. ships passing the Danish Sound, 1634-1857.

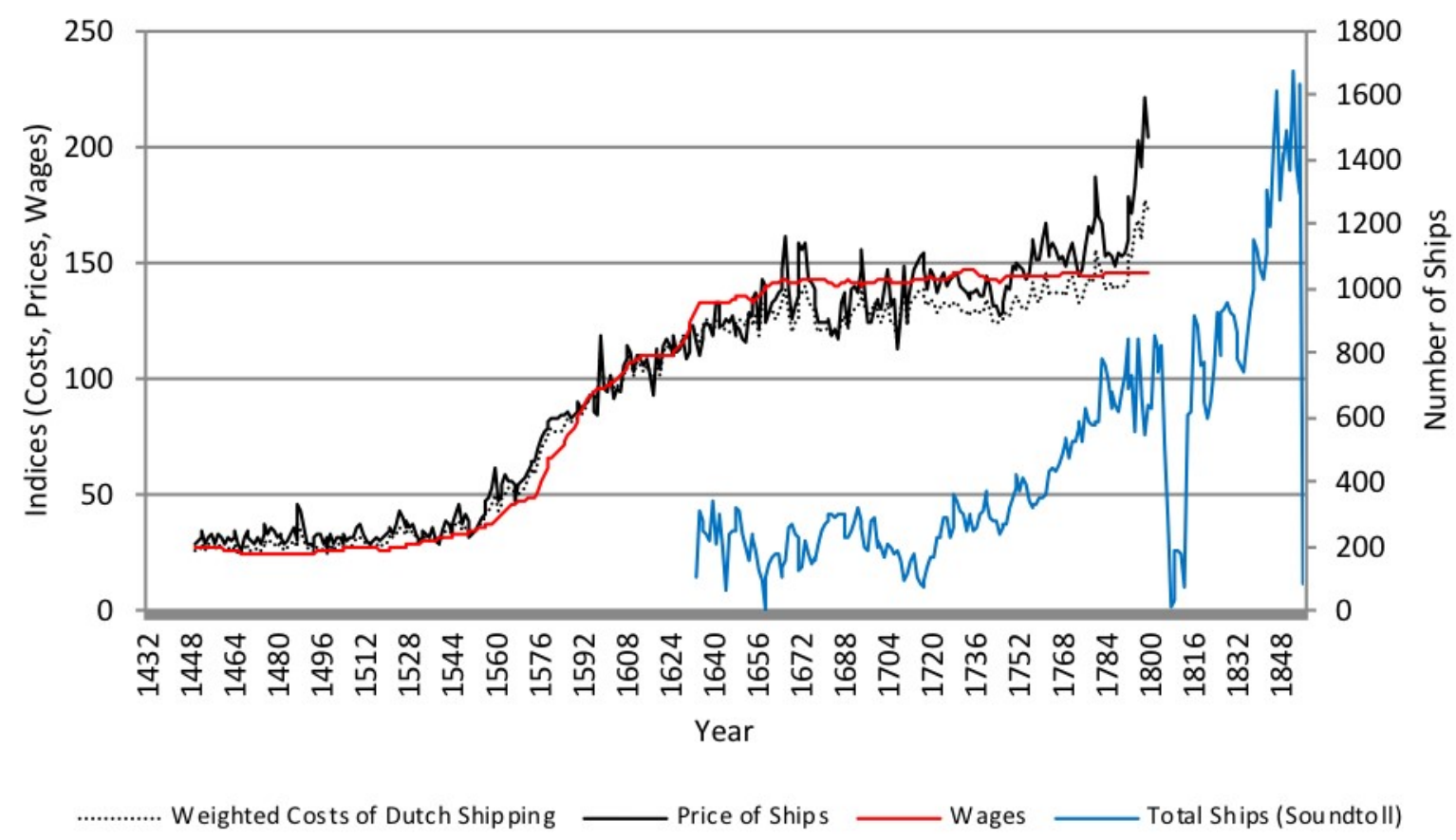

Source: van Zanden and van Tielhof (2009). On the Sound Toll records, see www.soundtoll.nl. (cited January 5,2018$).^{27}$

Typically the beginning of the first era of globalization is placed in the early 19th century, which also implies an immense growth in trade and shipping. ${ }^{28}$ As Figure 1.5 shows, the scale and scope of shipping increased (see the Dutch case) for centuries before the start of globalization in the 19th century, though others have challenged the view that it began even as late as this. ${ }^{29} \mathrm{We}$ also plotted the total number of ships that passed through the Danish Sound, which can be interpreted similarly, as an almost continuous growth trend in North European trade since the early 18th century. ${ }^{30}$ Smaller nations were the key players in the trade passing through the Sound, and they certainly joined in this expansion.

Figure 1.6

Index of world trade, 1800-1938 (1913 = 100) vs. ships passing the Danish Sound, 1634 1857. 


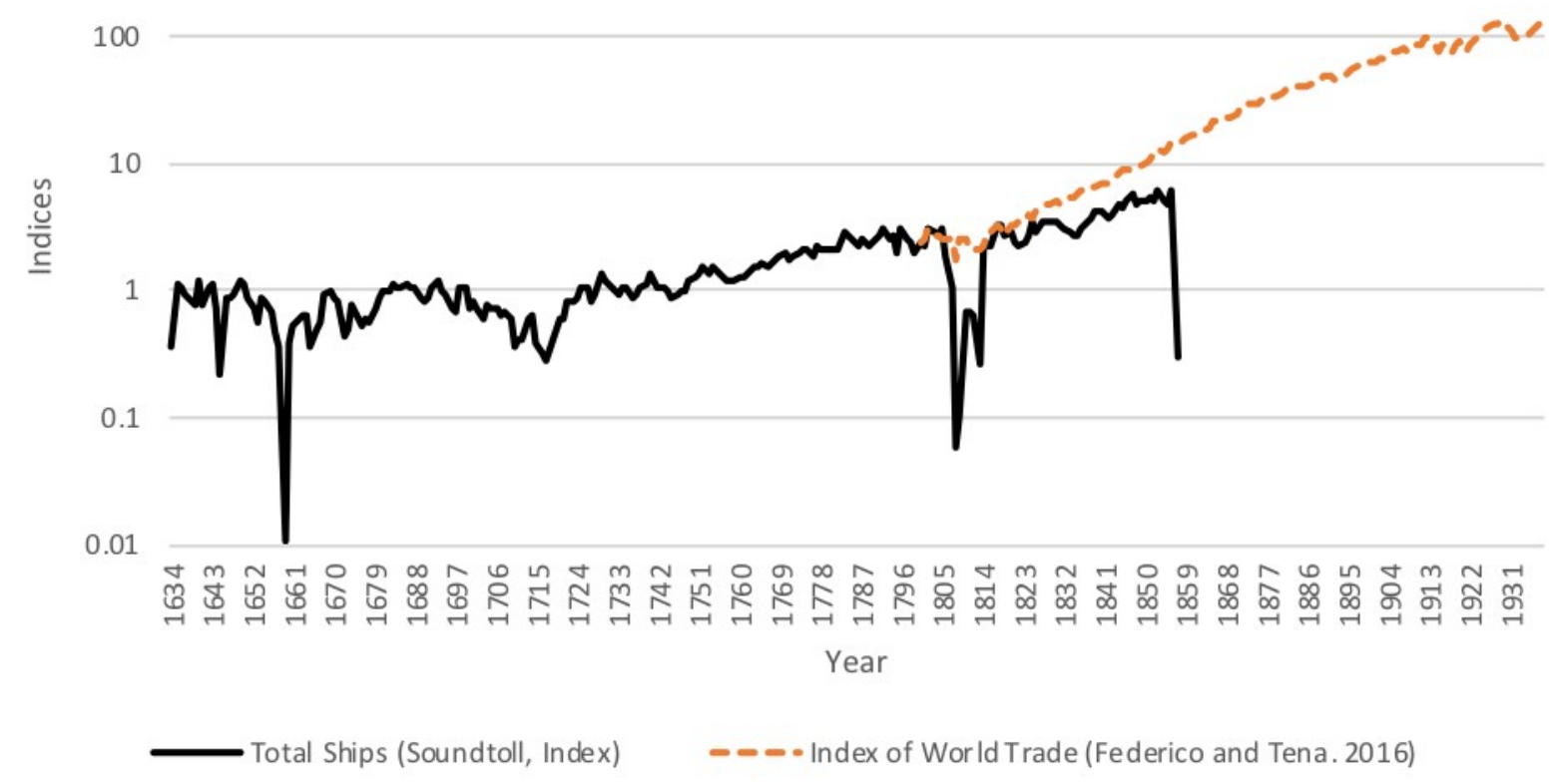

Sources: Federico, Giovanni; Tena Junguito, Antonio (2018a), "Federico-Tena World Trade Historical Database: World Trade", doi:10.21950/HPW2AK, e-cienciaDatos, V1; on the Sound Toll Records, see www.soundtoll.nl/index.php/en/onderzoek/zoeken-in-de-sonttol-database.

Note

The two indices were equalized at the year 1800 .

Figure 1.6 puts this in the context of 19th- and 20th-century trade, using the latest data from Giovanni Federico and Antonio Tena Junguito. It also gives the impression that the trade expansion in the 19th century may have been a continuation of an earlier pattern, albeit possibly timed later. Whether it was or not, the huge growth in trade in the 19th century is clearly impressive. The dips in the pattern show the effect of World War I and the 1930s Depressions.

The same database provides an overview of some of the costs of doing trade, namely freight rates. As earlier studies have suggested, freight rates declined in the 19th century, with the exception of a temporary bump in mid-century due to the Crimean War. ${ }^{31}$ World War I shows up as a massive peak, and so do the late 1930s. These results were confirmed by another data series and seem to match well. The decline in costs of course benefited all the states, and especially those with large merchant (and military) fleets.

Figure 1.7 
Global freight rates, 1800-1938.

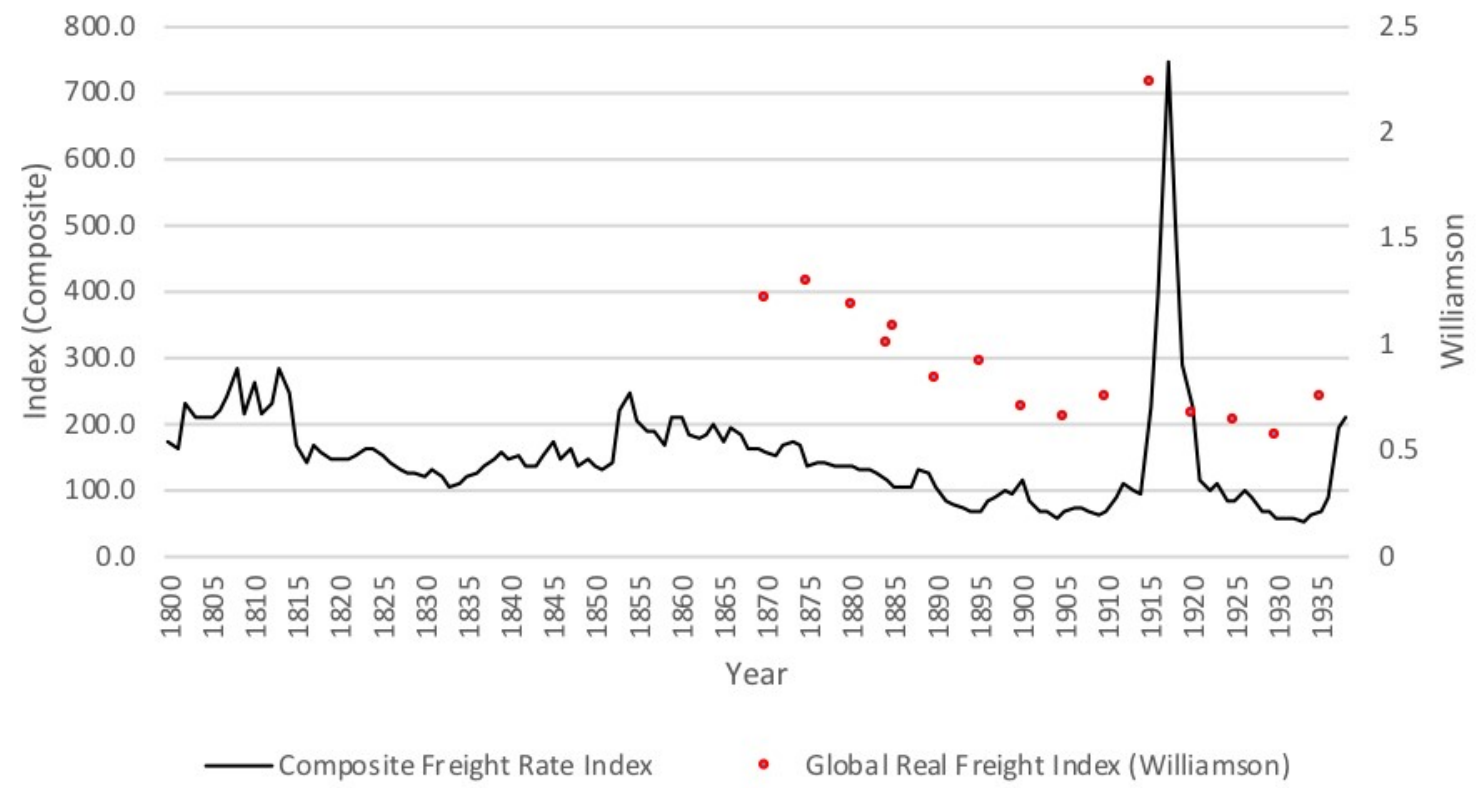

Sources: Federico, Giovanni; Tena Junguito, Antonio (2018b). 'Federico-Tena World Trade Historical Database: Freights rates", doi:10.21950/LAFKWD, e-cienciaDatos, V; and Mohammed and

Williamson (2004).

Note

The Federico-Tena Junguito freights were combined into an arithmetic mean.

Figure 1.8

World trade openness (= Exports/GDP), 1800-1938.

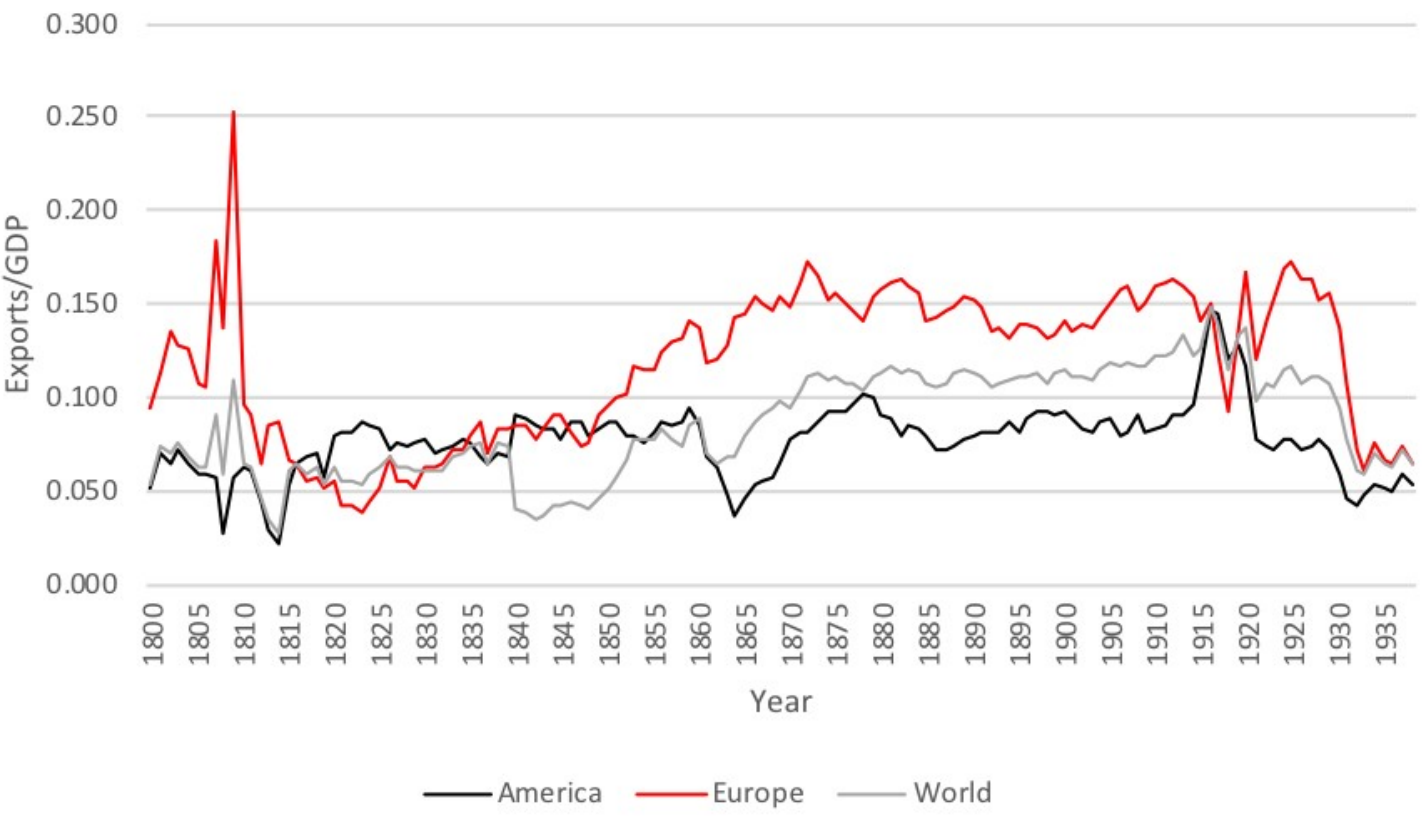


Source: Federico, Giovanni; Tena Junguito, Antonio (2018c). "Federico-Tena World Trade Historical Database: Openness", doi:10.21950/BBZVBN, e-cienciaDatos, V1. See also Federico and TenaJunguito (2017).

What about trade openness, which we have hypothesized as perhaps being a characteristic of a smaller/weaker nation? As seen in Figure 1.8, such openness increased above all in Europe, as a consequence of a network of free trade treaties later in the century. In the world as a whole, the increase was less pronounced, and the Americas remained more protectionist. World War I marked the end to this era of relative trade openness. But how do the smaller/weaker states fit into this picture? Figure 1.9 shows some of the states discussed in this book. Some countries, such as Brazil and Switzerland, were very open economies in this period, Sweden less so but increasingly between the wars. Portugal and the United States were not very open at all, and their dependence on foreign markets was low. Existing and former colonies helped the former to keep its economy fairly completely closed off, while the latter, in contrast with most of Europe, was fairly protectionist in the late 19th century,

Figure 1.9

Trade openness (= Exports/GDP) for select weak powers, 1800-1938.

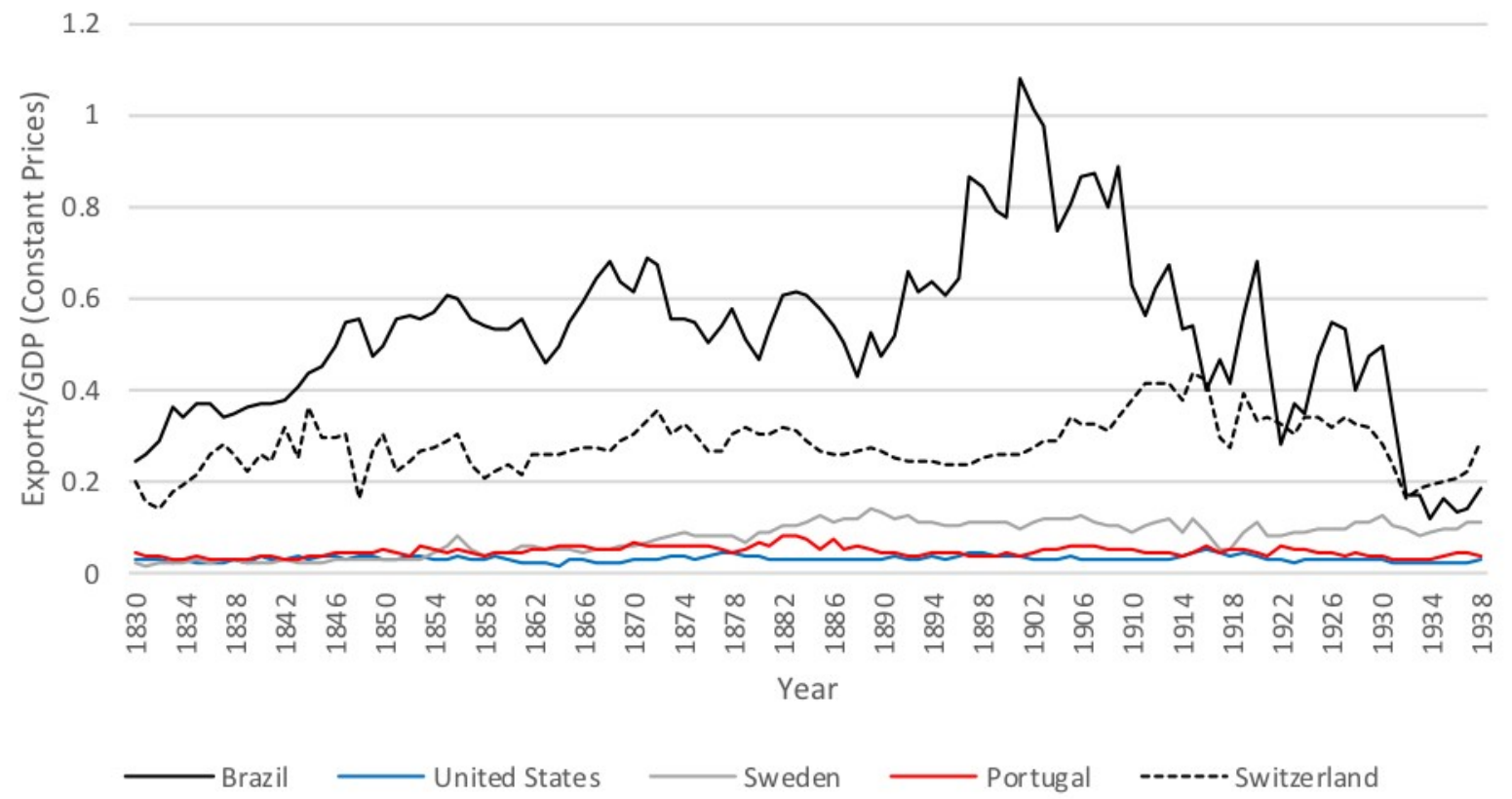

Source: Federico, Giovanni; Tena Junguito, Antonio (2018c). "Federico-Tena World Trade Historical Database: Openness", doi:10.21950/BBZVBN, e-cienciaDatos, V1. See also Federico and TenaJunguito (2017). 
Moreover, several of the chapters in this book examine the concept of neutrality, which small states have used as a way of avoiding direct conflict. Neutrality has long been seen as impartiality in war and is codified in international law as part of the Hague and Geneva Conventions. ${ }^{32}$ Although we have used this word across the chapters to describe how countries avoid conflict, the individual cases differ widely: consider Finland in the Cold War; Ireland, Spain, Switzerland, Sweden and others in World War II; all the Scandinavian countries in World War I. Neutrals have maintained their independence by offering economic and political concessions to the belligerents to make up for their absolute and relative smallness. Cooperation allows them to survive, but still to oppose the regimes against when they were ideologically hostile. However, despite their different starting places, challenges across a wide time period, and unique political and economic threats, the instances of neutrality mentioned in this work show a number of similarities. The credibility of this defense was tested in many areas; in this work we explore the trade and business effects of neutrality, particularly in Scandinavia and the Iberian Peninsula.

The argument presented in the chapters on neutrals in this book is developed on two discrete planes. The first area is explored in order to provide an economic history of small, neutral countries. In each conflict across the neutral case studies, trade is an area where neutrals were consistently threatened. Each of the chapters details elements of the trade and financial relations between the belligerent and neutral countries. Depending on the threats they faced, the neutrals cooperated to ensure their survival. Specific chapters also look at economic and business performance in light of the threats faced. These show how closely the neutral countries and businesses were affected by the war, but also how in the postwar periods they had a strategic advantage over competing firms, because of actions taken during the war.

The second area of inquiry is investigated in order to describe the bilateral relations between nations and the negotiations they engage in. As part of this process, powerful belligerents or groups of belligerents seek to influence neutral behavior - whether between Portugal and Russia in the late modern period, the Western alliance introducing an embargo on Finland during the Cold War to minimize the leakage of trade through Finland to the Soviet bloc, or the German and British embargos on Sweden during World Wars I and II. In the last two cases, informal cooperation with 
the Anglo-sphere existed; at each turning point in the various wars, Finland and Sweden had to provide evidence of cooperation to placate the belligerent parties.

Although many of the themes are the same, one strength of this volume is that the several chapters on small states and neutrality address a number of different cases to refine the concept of small state neutrality. For example, the trade and commercial relations between Portugal and Russia between 1770 and 1850 demonstrate the misalignment in trade aims due to problematic institutions and conflict. Norwegian neutrality in the Western blockade of Germany in World War I shows how vulnerable Norway became over time because of its unwillingness to negotiate in certain areas. In comparison, the business performance in Sweden during World War I of ball bearings manufacturer SKF displays how business can adapt to changing conditions during war. The macroeconomic effects of neutrality in the Nordic countries during the two world wars comparatively demonstrate a significant export improvement in the early years of World War I, but losses thereafter.

The lessons here show that neutrality was a tool used more and more by weaker states over time, but also that it was not always respected by the other players. The more important the output of the smaller state, and the greater their power to provide access to markets that were otherwise difficult for the belligerents to access, the more their neutrality status was respected. In such situations the weaker states could take advantage of the gaps in the limited wartime markets. These states could also operate between the confines of formal trade agreements, which were in any case abandoned during certain conflicts. In times of war their merchant fleets represented important conduits; and if they maintained enough of a military deterrent, their neutrality status was even more likely to be respected.

\section{Contributions of the volume}

The chapters in Part I, which focuses on the long-run interactions between trade and conflicts for smaller/weaker states, shed light on the reciprocal effects between war, or times of conflict, and trade. In Chapter 2, Eloranta, Land, and Moreira analyze the trading practices and trends for the United States from the beginning of its de facto independence, through the Revolutionary and Napoleonic Wars, and all the way to the period of peace in 1830 - during this time, the US was a new and weaker state. This is a longitudinal analysis of U.S. trade flows and behavior over a period that includes 
several conflicts and provides a fresh perspective on the role of the US as weak political actor. The economic impacts of war on trade are explored here, as well as the role of neutral and/or weaker states during such times, together with the pressure of the war efforts and whether they allowed more latitude for the US and other states to explore their trade options. Were there any changes in the types of goods traded over this complex period and, if so, what was the impact of the changes? Did economic and business concerns override political and diplomatic obstacles in these trade relations, and how did they open up opportunities for the smaller/weaker states? This chapter explores these points and argues that weak states, albeit briefly, were able to expand their trade and discover new markets even though they faced such large and protracted conflicts.

Silvia Marzagalli's contribution (Chapter 3) provides an evaluation of the role of American shipping and trade in the Mediterranean during the French Wars, and she shows how a country such as the United States could make the most of its situation and the wars in Europe to explore this trading area to its advantage. This chapter also underlines the relevance of guarantees for the United States' trade and the chance to take advantage of neutrality through peace treaties, commercial treaties, and consulates in major ports. According to Marzagalli's findings, American shipping into the Mediterranean increased five to six times from the early 1790s to 1807 , part of the trade being with belligerents. The United States' ease in handling belligerents' property relativized the notion of neutrality, giving it more flexibility and making it a system in constant evolution, rather than a fixed legal status. Despite the obstacles faced by the ships' crews, they still seized the chance to expand the country's stay in the Mediterranean and travel further east.

In Chapter 5, Dominguez and Carrara bring out a Brazilian historiographic panorama over the last three decades, following trade and taxation as a main conduit and depicting the establishment and consolidation of the two schools of thought regarding Brazil's economic history. In addition, the writers analyze the former Portuguese colony's fiscal capacities before and during the Napoleonic Wars, exploring in particular the case of Rio de Janeiro's supremacy over other major local provinces and Lisbon at the end of the 18th century and beginning of the 19th. 
Moreira, Sousa, and Scheltjens' study of the commercial relations between Portugal and Russia (Chapter 4) analyzes the trade patterns and finance between these two countries. They explore the commercial changes in the relations between these two markets and focus on the Baltic Sea region in the context of the major international changes between 1770 and 1850 entailed by the new global war, and on neutrality and peace, in particular after the American War of Independence and the Napoleonic War. This study also points out that the difficulties of navigation, organization, and finance for Portuguese trade are important variables in explaining the absence of Portuguese merchants from this region's commercial relations.

Chapter 6, by Hedberg and Häggqvist, covers how a neutrality stance was adopted, especially by Sweden, following the end of the Napoleonic Wars. Its origins were closely connected to foreign trade, where neutrality was a tool for the country to keep trade links open and to attempt to direct shipping through Swedish ports. This chapter examines Swedish foreign trade, shipping and wartime trade policy strategies during the Napoleonic Wars, the Crimean War, and World War I. Sweden was able to take advantage of its neutral position during these three wars to increase trade and shipping, but it also adjusted its trade policy as a result of the circumstances of war and the encompassing neutrality. The short- and long-run effects of these wars on trade policy are discussed.

In comparison, the chapters in Part II, which focuses on the impact of conflicts on trade and neutrality (and vice versa), open the door to in-depth analyses of conflict-era trade and neutrality. In Chapter 7, on neutrality and conflicts, Eric Golson contributes to the understanding of the origins of neutrality and its legal framework, linking it with a framework from economic history, namely, the analysis of trade, labor, and capital for small states and neutrals in times of conflict. He approaches the subject of neutrality by briefly discussing the concept in legal terms and describes how different scholars have viewed its evolution. This introduction leads to the legal codification of neutrality in legal conventions, providing a framework for the definition of relationships between states. However, this legal framework was often disregarded in practice and neutral states were deeply affected during the Great War and interwar period, which was critical for the concept of neutrality. The realist principles, and the 
fact that neutrals did not have access to trade and other services, led to a loss of power, the German encirclement being the most famed violation of neutrality.

In fact, the concept of neutrality has evolved over the centuries. Legally codified as impartiality, it took a realist turn with the events of World War II. It is clear nowadays that there cannot be a single rule that covers neutrality and the way in which a country should be able to protect itself. Neutral, small states were able to survive even in a war scenario, avoiding conflict by their own realism and practicality. Throughout the Great War, the Norwegian economy rose and fell with great speed. During this time, not only did the German demand for imports boost domestic production, but Norway also then became a hub for the trans-shipment of overseas goods. Strom explains in his contribution (Chapter 8) how the British government's failure to implement a coordinated system of blockade may explain how this could happen, in spite of the best efforts of the Entente. The Norwegian government implemented policies that had been made in the prewar era. However, in 1914, the British government controlled the connections between Norway and the West. Therefore, the British government would have had full power to overrule a Norwegian policy in order to avoid direct engagement with the blockade. Once the British government began implementing effective blockade measures, it was only a matter of time before Norway would become fully integrated into the blockade mounted by Germany.

Golson's second contribution (Chapter 9, with Jason Lennard), which centers on the study of Swedish economic and business performance during World War I, focuses on the importance of the Great War in the economic history of Sweden. The chapter proceeds with a microeconomic perspective to show how the war affected the economy at the level of an individual firm and how "the golden age" of the Swedish economy developed. Ball bearings manufacturer SKF saw a healthy boost and eventual longevity through international capital investment, vertical integration, the expansion of subsidiaries, and control of the Conrad ball bearings patent. The authors review the impact of World War I on the entire Swedish economy and Swedish businesses, as well as the flourishing movement and growth of SKF. The Swedish economy placed itself in context with the economic and business development of the time. Sweden's neutrality in this era is often overlooked or understated, but not in this chapter. This new study applies previous theories with updated statistics to the SKF 
case study. The SKF case during the war is unique because of the growth of competition against the company, but the extent of SKF's growth, in spite of all that was going against it, makes it intriguing to delve into. This study extends into both the Swedish economy and its business to demonstrate how dependent on the progress of Swedish businesses and how closely interlinked it was with the war. World War I was a pivotal time for the recognition of Swedish industry in international markets and set the tone for many years - well into the 1920s and beyond.

In the wake of World War I, the Nordic countries suffered only mildly, and generally recovered quickly. However, in Chapter 10, on the Nordic countries during the two world wars, Lennard and Golson discuss how much more they suffered in the second. They saw almost twice as much loss of output as they had seen during the Great Depression. Still, much of the lost economic activity in the wartime current accounts was mitigated when trade quickly increased afterwards. Meanwhile, countries such as Finland suffered in both wars. Isolation from traditional trading partners appears to have been a contributing factor to its losses. While the focus of this chapter is the short-run implications of the world wars on the Nordic economies, the long-run impacts were also a factor. Lennard and Golson provide a comprehensive methodology for measuring the economic effect of wars based on the cost of crisis in terms of lost output.

During the Cold War, the control of exports, especially protecting them from the influence of the Soviet bloc in the Eastern European countries, was extremely difficult. In Chapter 11, Jensen-Eriksen points out how much some of the officials and companies of the neutral countries wanted to limit the flow of militarily useful goods eastwards. Informal links and agreements made under the radar maintained the appearance of neutrality. This is why, Jensen-Eriksen says, it is important to look at low-level interaction. This study suggests that there was very little some countries could do about the field of export controls to the Eastern bloc. The Soviet Union, for example, could have used items embargoed by the Western alliance to help undermine the embargo itself. This underlines the fact that, the US in the early Cold War was not strong enough to totally eliminate the impulse to reap benefits from being declared neutral. Some of the neutrals believed that the strategic Western embargo was not an "East versus West" issue. It was a threat that forced neutral 
countries to curtail their exports of strategic goods, which sometimes came from the USA. Therefore, it had a major "West versus West" impact. They were concerned that they would have economic sanctions imposed on them or be shamed by their efforts to stay out of the global confrontation. Throughout this chapter, Jensen-Eriksen explores the advantages and disadvantages of neutrality.

In Chapter 12, the conclusion of this volume Jari Ojala and Toshiaki Tamaki discuss some of the findings and contributions of the book, as well as offering ideas for future research. This volume is just the first step in the process of reassessing the role and importance of smaller/weaker states in world trade, conflicts, and economic outcomes. Our assertion is that their role has been under-studied and underestimated. These nations were key players in the economic and political networks that functioned in the peripheries of the conflicts and of trade, when in many of these conflicts the peripheries were the only places for trading. The great powers had to dedicate their resources to protecting their own trade routes and/or imposing blockades, but they still needed the key commodities. Neutrality was a key tool for the smaller states to explore and exploit these opportunities over time.

As we have said, here we have just scratched the surface of the research opportunities that might be seized, as Patrick O'Brien also points out in his kind Foreword. First of all, we need a larger set of country studies to examine the bilateral and multilateral trade flows over longer periods of time, especially to develop largescale databases for comparisons. Second, as in this volume, our approach is still too much dominated by European historical cases and descendants of the British Empire we need a broader coverage of different world regions, and a better balance between colonial mother countries and the colonies themselves. Third, we need comprehensive long-run data on these states, to engage in deeper data analysis, so we can also quantitatively test the ideas explored here. Fourth, we see a dichotomy between the smaller/weaker states and the type of state capacity they had, when it came to conflicts and trade, in various historical contingencies. Finally, we need deeper analyses of the types of conflict they were involved in and the economic consequences of these conflicts, which would link our analyses with the larger literature of state capacity, fiscal states, long-run trade, the economic history of conflicts, and the long-run macroeconomic development of polities. 


\section{References}

Acemoglu, D. (2005). Politics and economics in weak and strong states. Journal of monetary Economics, 52(7), 1199-1226.

Acemoglu, D., \& Robinson, J. A. (2013). Why nations fail: The origins of power, prosperity, and poverty. New York: Broadway Business.

Acemoglu, D., Garcia-Jimeno, C., \& Robinson, J. A. (2015). State capacity and economic development: A network approach. American Economic Review, 105(8), 2364-2409.

Acemoglu, D., Ticchi, D., \& Vindigni, A. (2011). Emergence and persistence of inefficient states. Journal of the European Economic Association, 9(2), 177-208.

Acemoglu, D., Vindigni, A., \& Ticchi, D. (2010). Persistence of civil wars. Journal of the European Economic Association, 8(2-3), 664-676.

Adams Jr, D. R. (1980). American neutrality and prosperity, 1793-1808: A reconsideration. Journal of Economic History, 40(4), 713-737.

Alimento, A. (2011). War, trade and neutrality: Europe and the Mediterranean in the seventeenth and eighteen centuries, vol. 400. Milan: FrancoAngeli.

Aunesluoma, J. (2003). Britain, Sweden and the Cold War, 1945-54: Understanding neutrality. New York: Springer.

Bell, D. (2007). The first total war: Napoleon's Europe and the birth of warfare as we know it. New York: Houghton Mifflin Harcourt.

Besley, T., \& Persson, T. (2009). The origins of state capacity: Property rights, taxation, and politics. American Economic Review, 99(4), 1218-1244.

Besley, T., \& Persson, T. (2010). State capacity, conflict, and development. Econometrica, 78(1), 1-34.

Blomberg, S. B., \& Hess, G. D. (2006). How Much does Violence Tax Trade? Review of Economic Studies and Statistics, 88(4), 599-612.

Bolt, J., \& Zanden, J. L. (2014). The Maddison Project: collaborative research on historical national accounts. The Economic History Review, 67(3), 627-651.

Bonney, R. (Ed.) (1999). The Rise of the Fiscal State in Europe c. 1200-1815. Oxford: Oxford University Press.

Broadberry, S. (2016). The great divergence in the world economy: long-run trends of real income. In Joerg Baten (ed.), A history of the global economy: 1500 to the present. Cambridge, UK: Cambridge University Press. 
Broadberry, S., \& Gardner, L. (2016). Economic development in Africa and Europe: Reciprocal comparisons. Revista de Historia Economica-Journal of Iberian and Latin American Economic History, 34(1), 11-37.

Broadberry, S., \& Harrison, M. (2005). The economics of World War I: An overview. In S. Broadberry \& M. Harrison (Eds.), The economics of World War I. Cambridge, UK: Cambridge University Press.

Broadberry, S., \& Harrison, M. (2006). The economics of World War I: A comparative quantitative analysis. Journal of Economic History, 66(2), 514-514.

Crisher, B. B., \& Souva, M. (2014). Power at sea: A naval power dataset, 1865-2011. International Interactions, 40(4), 602-629.

Crouzet, F. (1964). Wars, blockade, and economic-change in Europe, 1792-1815. Journal of Economic History, 24(4), 567-588.

Davis, L., \& Engerman, S. L. (2006). Naval blockades in peace and war: An economic history since 1750. New York: Cambridge University Press.

de Jong, H. (2005). The Dutch economy during World War I. In S. Broadberry \& M. Harrison (Eds.), The economics of World War I. Cambridge, UK: Cambridge University Pres.

De Pleijt, A. M., \& Van Zanden, J. L. (2016). Accounting for the "little divergence": What drove economic growth in pre-industrial Europe, 1300-1800? European Review of Economic History, 20(4), 387-409.

De Vries, J. (2010). The limits of globalization in the early modern world. Economic History Review, 63(3), 710-733.

Dincecco, M. (2011). Political transformations and public finances: Europe, 1650 1913. Cambridge, UK: Cambridge University Press.

Dincecco, M., \& Prado, M. (2012). Warfare, fiscal capacity, and performance. Journal of Economic Growth, 17(3), 171-203.

Drelichman, M., \& Voth, H.-J. (2014). Lending to the borrower from hell: Debt, taxes, and default in the age of Philip II. Princeton, NJ: Princeton University Press.

Eloranta, J. (2002). European states in the international arms trade, 1920-1937: The impact of external threats, market forces, and domestic constraints. Scandinavian Economic History Review, 50(1), 44-67. 
Eloranta, J. (2007). From the great illusion to the Great War: Military spending behaviour of the Great Powers, 1870-1913. European Review of Economic History, 11(2), 255-283.

Eloranta, J. (2017). Pro bono publico? Demand for military spending between the world wars. Essays in Economic \& Business History, 35(2), 99-142.

Eloranta, J., Andreev, S., \& Osinsky, P. (2014). Democratization and central government spending, 1870-1938: Emergence of the leviathan? In C. Hanes \& S. Wolcott (Eds.), Research in Economic History (vol. 30, pp. 1-46). Bingley, UK: Emerald Group Publishing.

Federico, G., \& Tena-Junguito, A. (2017). A tale of two globalizations: Gains from trade and openness 1800-2010. Review of World Economics, 153(3), 601-626.

Ferguson, N. (2001). The cash nexus: Money and power in the modern world, 17002000. New York: Basic Books.

Findlay, R., \& O'Rourke, K. H. (2007). Power and plenty: Trade, war, and the world economy in the second millennium. Princeton, NJ: Princeton University Press.

Frank, A. G., \& Denemark, R. A. (2015). Reorienting the 19th century: Global economy in the continuing Asian age. London: Routledge.

Frankel, J. A. (1982). The 1807-1809 embargo against Great Britain. Journal of Economic History, 42(2), 291-307.

Frey, M. (1997). Trade, ships, and the neutrality of the Netherlands in the First World War. International History Review, 19(3), 541-562.

Gennaioli, N., \& Voth, H.-J. (2015). State capacity and military conflict. Review of Economic Studies, 82(4), 1409-1448.

Gilpin, R. (2016). The political economy of international relations. Princeton, NJ: Princeton University Press.

Glick, R., \& Taylor, A. M. (2010). Collateral damage: Trade disruption and the economic impact of war. Review of Economics and Statistics, 92(1), 102-127.

Gøbel, E. (2010). The sound toll registers online project, 1497-1857. International Journal of Maritime History, 22(2), 305-324.

Gowa, J., \& Hicks, R. (2015). Commerce and conflict: New data about the Great War. British Journal of Political Science, 47(3), 1-22.

Häggqvist, H. (2015). On the ocean of protectionism. The structure of Swedish tariffs and trade 1780-1830, vol. 103. Uppsala: Acta Universitatis Upsaliensis; Uppsala University Library. 
Halpern, P. (2006). World War I: The blockade. In L. Davis \& S. L. Engerman (Eds.), Naval blockades in peace and war: An economic history since 1750. New York: Cambridge University Press.

Handel, M. I. (1981). Weak states in the international system. London, UK?Totowa, NJ: F. Cass.

Handel, M. I. (1990). Weak states in the international system: London: F. Cass.

Harley, C. K. (1988). Ocean freight rates and productivity, 1740-1913: The primacy of mechanical invention reaffirmed. Journal of Economic History, 48(4), 851876.

Harrison, M. (1998). The economics of World War II: An overview. In M. Harrison (Ed.), The economics of World War II. Cambridge, UK: Cambridge University Press.

Hautcoeur, P.-C. (2005). The economics of World War I in France. In S. Broadberry \& M. Harrison (Eds.), The Economics of World War I. Cambridge, UK: Cambridge University Press.

Heckscher, E. F. (1964). The Continental System: An economic interpretation. Gloucester, MA: Peter Smith.

Hedberg, P. (2016). The impact of WWI on Sweden's foreign trade and growth. Journal of European Economic History, 45(3).

Hedberg, P., \& Karlsson, L. (2015). Neutral trade in time of war: The case of Sweden, 1838-1960. International Journal of Maritime History, 27(1), 61-78.

Hendrix, C. S. (2010). Measuring state capacity: Theoretical and empirical implications for the study of civil conflict. Journal of Peace Research, 47(3), 273-285.

Hoffman, P. T. (2015). Why did Europe conquer the world? Princeton, NJ: Princeton University Press.

Inklaar, R., de Jong, H., Bolt, J., \& van Zanden, J. (2018). Rebasing “Maddison”: New income comparisons and the shape of long-run economic development. Working Paper GD-174, GGDC Research Memorandum from Groningen Growth and Development Centre, University of Groningen.

Jacks, D. S. (2006). What drove 19th century commodity market integration? Explorations in Economic History, 43(3), 383-412.

Jacks, D. S., Meissner, C. M., \& Novy, D. (2010). Trade costs in the first wave of globalization. Explorations in Economic History, 47(2), 127-141. 
Jacks, D. S., O’Rourke, K. H., \& Williamson, J. G. (2011). Commodity price volatility and world market integration since 1700. Review of Economics and Statistics, 93(3), 800-813.

Joenniemi, P. (1998). From small to smart: Reflections on the concept of small states. Irish Studies in International Affairs, 9, 61-62.

Johnson, N. D., \& Koyama, M. (2014). Tax farming and the origins of state capacity in England and France. Explorations in Economic History, 51, 1-20.

Ju, C. (2017, July 18). Causes of war: When the unknown creates false optimism. Chicago Policy Review. Retrieved from http://chicagopolicyreview.org/2017/07/18/causes-of-war-when-the-unknowncreates-false-optimism/

Kalemli-Özcan, Ș., Reinhart, C., \& Rogoff, K. (2016). Sovereign debt and financial crises: Theory and historical evidence. Journal of the European Economic Association, 14(1), 1-6.

Kassimeris, C. (2009). The foreign policy of small powers. International Politics, 46(1), 84-101.

Kennedy, P. (1989). The rise and fall of the great powers. Economic change and military conflict from 1500 to 2000. London: Fontana.

Kennedy, P. M. (1988). The rise and fall of the great powers: economic change and military conflict from 1500 to 2000. London: Unwin Hyman.

Lamoreaux, J. W., \& Galbreath, D. J. (2008). The Baltic states as "small states": Negotiating the "East" by engaging the "West". Journal of Baltic Studies, 39(1), $1-14$.

Land, J., \& Eloranta, J. (2016). Wartime economies, 1939-1945: Large and small European states at war. In N. Doumanis (Ed.), The Oxford Handbook of European History, 1914-1945 (pp. 461-479): Oxford, UK: Oxford University Press.

Lindert, P. H. (2003). Voice and growth: Was Churchill right? Journal of Economic History, 63(2), 315-350.

Lindert, P. H. (2004). Growing public: Social spending and economic growth since the eighteenth century, vol. 1. Cambridge, UK: Cambridge University Press.

Little, D. (1985). Malevolent neutrality: The United States, Great Britain, and the origins of the Spanish Civil War. Ithaca, NY: Cornell University Press. 
Maass, M. (2009). The elusive definition of the small state. International Politics, $46(1), 65-83$.

Marzagalli, S., \& Müller, L. (2016). "In apparent disagreement with all law of nations in the world": Negotiating neutrality for shipping and trade during the French Revolutionary and Napoleonic Wars. International Journal of Maritime History, 28(1), 108-117.

Meredith, D. (2016). British economic growth, 1270-1870, ed. Stephen Broadberry, Bruce S. M. Campbell, Alexander Klein, Mark Overton \& Bas van Leeuwen: Oxford, UK: Oxford University Press.

Milward, A. S. (1977). War, economy and society, 1939-1945. London: Lane.

Modelski, G., \& Thompson, W. R. (1988). Seapower in global politics, 1494-1993. Basingstoke, UK: Macmillan.

Modelski, G., \& Thompson, W. R. (1996). Leading sectors and world powers. The coevolution of global politics and economics. Columbia: University of South Carolina Press.

Mohammed, S. I. S., \& Williamson, J. G. (2004). Freight rates and productivity gains in British tramp shipping 1869-1950. Explorations in Economic History, 41(2), 172-203.

Moreira, C., \& Eloranta, J. (2011). Importance of «weak» states during conflicts: Portuguese trade with the United States during the Revolutionary and Napoleonic wars. Revista de Historia Económica, 29(03), 393-423.

Moreira, M. C., Eloranta, J., Ojala, J., \& Karvonen, L. (2015). Early modern trade flows between smaller states: The Portuguese-Swedish trade in the eighteenth century as as example. Revue de l'OFCE, 140, 87-109.

Müller, L. (2016). Swedish merchant shipping in troubled times: The French Revolutionary Wars and Sweden's neutrality 1793-1801. International Journal of Maritime History, 28(1), 147-164.

Müller, M. (2009). Coping with barriers to trade: Causes and consequences of the changing competitiveness of Swiss industries (1900-1950). Paper presented at the EBHA, 12th Annual Conference, Bergen.

North, D. (1958). Ocean freight rates and economic development 1730-1913. Journal of Economic History, 18(4), 537-555. 
O'Grada, C. and Kelly, M. (2017). Speed under sail, during the early Industrial Revolution (c.1750-1850) (October 12, 2017). Retrieved from https://ssrn.com/abstract=2412955 or http://dx.doi.org/10.2139/ssrn.2412955

O'Rourke, K. H. (2006). The worldwide economic impact of the French Revolutionary and Napoleonic Wars, 1793-1815. Journal of Global History, 1(1), 123-149.

O’Rourke, K. H., \& Williamson, J. G. (2002). When did globalisation begin? European Review of Economic History, 6(1), 23-50.

O'Rourke, K. H., \& Williamson, J. G. (2001). Globalization and history: The evolution of a nineteenth-century Atlantic economy. Boston, MA: MIT Press.

O'Rourke, K. H., \& Williamson, J. G. (2004). Once more: When did globalisation begin? European Review of Economic History, 8(1), 109-117.

Ojala, J., \& Eloranta, J. (2015). Sweden and Finland c. 1700-1809, Finland 1809-c. 1850. Revue de l'OFCE, 140, 373-377.

Parchami, A. (2009). Hegemonic peace and empire: The Pax Romana, Britannica and Americana: London: Routledge.

Pinilla, V., \& Vicente, R. (2008). The agricultural and food trade in the first globalization: Spanish table wine exports 1871 to 1935. Journal of Wine Economics, 3(2), 132-148.

Rauch, C. (2017). Challenging the power consensus: GDP, CINC, and Power Transition Theory. Security Studies, 26(4), 642-664.

Reinhart, C. M., \& Rogoff, K. S. (2014). Recovery from financial crises: Evidence from 100 episodes. American Economic Review, 104(5), 50-55.

Rota, M. (2016). Military spending, fiscal caf and the democracy puzzle. Explorations in Economic History, 60, 41-51.

Sabaté, O. (2016). New quantitative estimates of long-term military spending in Spain (1850-2009). In C. Hanes \& S. Wolcott (Eds.), Research in Economic History (vol. 32, pp. 225-276). Bingley, UK: Emerald Group Publishing Limited.

Salmon, P. (2002). Scandinavia and the great powers 1890-1940. Cambridge, UK: Cambridge University Press.

Sarkees, M. R., \& Wayman, F. W. (2010). Resort to war: A data guide to inter-state, extra-state, intra-state, and non-state wars, 1816-2007. Washington: CQ Press. 
Scheltjens, W., \& Veluwenkamp, J. W. (2012). Sound Toll Registers online: Introduction and first research examples. International Journal of Maritime History, 24(1), 301-330.

Schroeder, P. (1994). Historical reality vs. neo-realist theory. International Security, 19(1), 108-148.

Singer, J. D., Bremer, S., \& Stuckey, J. (1972). Capability distribution, uncertainty, and major power war, 1820-1965. In B. Russett (Ed.), Peace, war, and numbers (pp. 19-48). Beverly Hills, CA: Sage.

Stasavage, D. (2002). Credible commitment in early modern Europe: North and Weingast revisited. Journal of Law, Economics, and Organization, 18(1), 155186.

Stasavage, D. (2011). States of credit: Size, power, and the development of European polities: Princeton, NJ: Princeton University Press.

Tilly, C. (1990). Coercion, capital, and European states, AD 990-1990. Cambridge, MA: Basil Blackwell.

van Zanden, J. L., \& van Tielhof, M. (2009). Roots of growth and productivity change in Dutch shipping industry, 1500-1800. Explorations in Economic History, 46(4), $389-403$.

Welling, G. M. (1998). The prize of neutrality: Trade relations between Amsterdam and North America 1771-1817. Dissertation, University of Groningen.

Wohlforth, W. C. (1987). The perception of power: Russia in the pre-1914 balance. World Politics, 39(3), 353-381.

Yun-Casalilla, B., O'Brien, P. K., \& Comín, F. C. (2012). The rise of fiscal states: A global history, 1500-1914: Cambridge, UK: Cambridge University Press.

\section{Notes}

1 On the concept of small states, see Joenniemi (1998); Kassimeris (2009); Maass (2009). On the Baltic states in this context, see Lamoreaux and Galbreath (2008).

2 See e.g. Acemoglu (2005); Acemoglu, Ticchi, and Vindigni (2011); Acemoglu, Vindigni, and Ticchi (2010).

3 Handel (1981, 1990).

4 Eloranta, (2002). This is further discussed in Salmon (2002).

5 See e.g. Gilpin (2016); Kennedy (1989); Parchami (2009); Schroeder (1994). 
6 For example, see Acemoglu, Garcia-Jimeno, and Robinson (2015); Acemoglu and Robinson (2013); Besley and Persson (2009, 2010); Dincecco (2011); Dincecco and Prado (2012); Gennaioli and Voth (2015); Hendrix (2010); Johnson and Koyama (2014).

7 Such as Bonney (1999); Ferguson (2001); Hoffman (2015); Lindert (2003, 2004); Stasavage (2002, 2011); Yun-Casalilla, O'Brien, and Comín (2012).

8 Many of these arguments are grounded in Tilly (1990).

9 In addition to the literature already cited, see especially the case of Spain in Drelichman and Voth (2014). For a broader analysis of public debt patterns and financial crises, see Kalemli-Özcan, Reinhart, and Rogoff (2016); Reinhart and Rogoff (2014).

10 Singer, Bremer, and Stuckey (1972).

11 Some of this discussion can be seen in the following: Eloranta (2017); Ju (2017); Rauch (2017); Wohlforth (1987). Also, in older conflicts other products and resources could play a more decisive role.

12 On comparative figures for the late 19th and early 20th centuries, see, e.g., Eloranta (2007); Eloranta, Andreev, and Osinsky (2014); Rota (2016); Sabaté (2016).

13 Bolt and Zanden (2014); Broadberry (2016); Broadberry and Gardner (2016); de Pleijt and van Zanden (2016); Meredith (2016).

14 See, e.g., Modelski and Thompson $(1988,1996)$.

15 Crisher and Souva (2014).

16 Modelski and Thompson (1988).

17 Bell (2007); Land and Eloranta (2016); Moreira and Eloranta (2011); Moreira, Eloranta, Ojala, and Karvonen (2015).

18 Findlay and O'Rourke (2007).

19 There is plenty of literature available on the impact of war and blockades on the economy. On the French Revolutionary and the Napoleonic Wars, see, e.g., Crouzet (1964); Frankel (1982); Heckscher (1964); O'Rourke (2006). On the economic conditions during World Wars I and II, see Broadberry and Harrison (2006); Harrison (1998); Milward (1977).

20 See, e.g., Gowa and Hicks (2015),

21 Chapter 1 in Broadberry and Harrison (2005); Kennedy (1988).

22 Glick and Taylor (2010). 
23 Blomberg and Hess (2006).

24 On the experiences of, e.g., the Scandinavian countries during the Napoleonic Wars and World War I, see Häggqvist (2015); Hedberg (2016); Hedberg and Karlsson (2015); Müller (2016); on Spain, see Pinilla and Vicente (2008); on Switzerland, see Müller (2009); on Dutch trade, see de Jong (2005); on belligerent US, Australia, Canada, and South Africa, as well as India, all countries were out of reach of war activities and blockades, see Findlay and O'Rourke (2007) and Hautcoeur (2005).

25 However, it should be noted that the practices of maritime neutral trade have been contested repeatedly in different wars and between countries, and accordingly, immense legal, diplomatic, political, and economic negotiations have been produced in order to reach agreements. The interpretations of neutrality have thus diverged greatly, and the arbitrary nature of the issue is illustrated by the fact that neutral merchant vessels sometimes were accompanied by armed escorts, and as a result, blockade policies of belligerent countries subsequently triggered wars between the neutral and the belligerent country. While neutrals have claimed that "free ships make free goods", the stance of belligerents have differed varied according to the different neutrals (Marzagalli \& Müller, 2016), p. 113). If neutral merchants were considered enhancing the military capacity of the enemy side, they often became targeted - such as during World War I, when Germany and the British took aim at the neutral vessels trading with the enemy, see, e.g., Davis and Engerman (2006) and Halpern (2006). But, from the view of the belligerent country, the use of blockade strategies comprised a dilemma: on the one hand, allowing neutral countries to trade unreservedly might benefit the enemy side and extend the duration of the war, but, on the other, too strict an attitude would have risked that the neutral even joined the enemy as well, and accordingly a loss of a supplier of precious commodities.

26 For instance, neutral Sweden's trade and terms of trade during the Crimean War and the Franco-Prussian War experienced a short- and long-term positive impact, making a significant contribution to Swedish real GDP growth rates; see Hedberg and Karlsson (2015).

27 As examples of other trade databases for the period, see, e.g., TradHist (www.cepii.fr/cepii/en/bdd_modele/presentation.asp?id=32), which provides bilateral trade data for the period 1827-2014, and Ricardo Project 
(http://ricardo.medialab.sciences-po.fr/\#/), which has trade data for the period 18001938.

28 Jacks (2006); Jacks, Meissner, and Novy (2010); Jacks, O'Rourke, and Williamson (2011); O'Rourke and Williamson (2001, 2002, 2004).

29 See, e.g., De Vries (2010); Frank and Denemark (2015). In turn, O'Grada and Kelly (2017), for example, argue that a major increase in ship speed occurred in the latter part of the 18th century.

30 Gøbel (2010); Moreira et al. (2015); Ojala and Eloranta (2015); Scheltjens and Veluwenkamp (2012).

31 Harley (1988); North (1958).

32 A small sampling of articles and books relating to the wars and trade of the weaker nations would include: Adams Jr. (1980); Alimento (2011); Aunesluoma (2003); Frey (1997); Little (1985); Marzagalli and Müller (2016); Müller (2016); Welling (1998). 